\title{
Farklılıkla Öğrenme Antrenmanlarının Basketbol Oyuncuları Üzerindeki Etkisi ${ }^{*}$
}

\author{
The Effects of Differential Learning Training on Basketball Players ${ }^{\star}$
}

\author{
Murat ÖZÇELİK ${ }^{* *}$ \\ Aytekin ALPULLU**
}

$\ddot{O} z$

Antrenmanın başlıca amacı sporcuları müsabakalara en iyi şekilde hazırlamaktır. Genel hatlarıyla incelendiğinde antrenman yöntemleri, doğrusal ve farklılıkla öğrenme olarak iki ana öğrenme yöntemi içermektedir. Fakat hangi yöntemin daha etkili olduğu konusunda tartışmalar devam etmektedir. Yaptığımız bu çalışmanın amacı farklılıkla öğrenme yönteminin antrenman programlarına eklenip 1618 yaş aralığındaki yarışmacı genç erkek takım basketbol oyuncularının, basketbol sporunun temeli olan pas verme, şut atma, top sürme ve turnike parametreleri üzerindeki etki ve gelişimlerini test etmek ve bu konudaki literatür açı̆ı̆ını doldurmaktır.

16-18 yaş aralığındaki UPS Spor ve Kültür Kulübü Yarışmacı Basketbol Genç takımı oyuncularından gönüllü olarak 24 erkek sporcu bu çalışmada yer almıştır. Çalışmada basketbol becerilerini test amacıyla German Heidelberger Basketball Test kullanılmıştır. Oyuncular 12' şer kişilik kontrol ve deney grubu olarak ayrıldıktan sonra ön teste tabii tutulmuştur. Ön test sonrası sekiz hafta boyunca haftada dört gün, deney grubuna, farklılıkla öğrenme yöntemi ile zenginleştirilmiş basketbol antrenman programı takip ettirilmiştir. Kontrol grubu ise altı gün boyunca olağan basketbol antrenman programlarına devam etmişlerdir.

Analiz sonuçları için SPSS Statistics 23.0 programında Wilcoxon testi ve denekler arasındaki anlamlı farklılık için ise T testi yapılmıştır. Beceri testinde ön test ile son test arasında istatistiksel olarak anlamlı fark bulunmuş̧tur $(\mathrm{p}<0.05)$. Kontrol ve deney grubu arasındaki anlamlı farka baktığımız T testinde iki grup arasındaki tüm becerilerde anlamlı farklılık bulunmuştur. $(\mathrm{p}<0.05)$.

Anahtar Kelimeler: Farklılıkla Öğrenme, Basketbol, Motor Beceri, Öğrenim Teorisi, Heidelberger Basketbol Testi

\footnotetext{
* Bu çalışma "Farklılıkla Öğrenme Antrenmanlarının Basketbol Oyuncuları Üzerindeki Etkisi” başlıklı yüksek lisans tezinden üretilmiştir. Marmara Üniversitesi, Sağlık Bilimleri Enstitüsü. Yıl: 2019. Murat Özçelik.

** Yüksek lisans öğrencisi. Marmara Üniversitesi. Sağlık Bilimleri Enstitüsü muratozcelik7@hotmail.com

*** Dr. Öğretim Üyesi. Marmara Üniversitesi. Spor Bilimleri Fakültesi. aytekin.alpullu@marmara.edu.tr
}

Geliş tarihi: 13.3.2019, Kabul tarihi: 30.05.2019 


\begin{abstract}
The aim of the training is to prepare the athletes for the competition. The selected training program should be the most ideal program. Generally speaking, there are two main methods of learning with differential and traditional training. The aim of this study is to test the effect and development of the competitor young man basketball players, who are 16-18 years old, in basketball, which is the basis of basketball sport, on the pass, shot, dribbling and lay up parameters.

UPS Sports and Culture Club Competitor Man Basketball Youth team players between the ages of 16-18 took part in this study voluntarily. German Heidelberger Basketball Test was used to test basketball skills and 24 athletes were included in the study. After the pre-test, for eight weeks, four days a week, the control group is followed by the traditional basketball team training, while the experimental group is followed by the basketball training program enriched with the learning method.

Wilcoxon test was used for SPSS Statistics 23.0 program and $\mathrm{T}$ test was used for significant differences between subjects. There was a statistically significant difference between pre-test and post-test performance of the players $(\mathrm{p}<0.05)$. In addition, in the T test, we found a significant difference between the two groups in all skills and that significants shows us differential training program more usefull than traditional training in this study between experimental and control group $(\mathrm{p}<0.05)$.
\end{abstract}

Keywords: Differential Learning, Basketball, Motor Skill, Learning Theory, Heidelberger Basketball Test

\title{
GiRiş
}

Antrenmanlarda esas olarak amaçlanan antrenmanın en yüksek seviyede sporcuya yararlı olmasıdır. Bunu sağlayan en önemli etken ise yapılan antrenmanın performansa direkt olarak olumlu yansımadır (Shoenfelt ve ark., 2002). Dolayısıyla, sporcuya yaptırılan uygulama döngüsü, antrenmanın etkinliğini en üst düzeye çıkarmak için ayrılmaz bir faktördür (Schmidt, 1975). Bir antrenman periyodunun içerisinde antrenman yönteminin olağan veya değişken olması arasında antrenman verimi açısından farklılıklar doğmaktadır. Olağan antrenman periyodunda amaçlanan hareket devamlı olarak aynı koşullar altında ve aynı davranış modeli ile gerçekleştirilirken, değişken antrenman periyodu dahilinde değişen koşullar altında hareket tamamlanmaktadır. Bu iki yöntem arasında olağan antrenman yöntemleri hareketi otomatikleştirmeyi sağlarken, değişken antrenman yöntemi ise farklı durumlara adaptasyonu kolaylaşmaktadır (Schöllhorn ve ark., 2010). Bununla birlikte, değişken uygulama avantajlarının, görevi otomatik hale getiren, tutarlı işlerden çok daha fazla olduğu ileri sürülmüştür. (Shea ve Kohl, 1990; Schmidt ve Bjork, 1992; Bjork, 1994; Ghodsian ve ark., 1997).

Değişken antrenman yönteminin avantajı motor becerileri başarılı bir öğrenme, bellekte tutma ve transfer etme olarak özetlenebilmektedir. Bu yöntemlerden bir tanesi ise 1999'da Schöllhorn tarafından ortaya konulmuş olan farklılıkla öğrenme antrenman yöntemidir. Bu yöntem aynı zamanda değişken antrenman yöntemlerinin temsilcisidir (Schöllhorn ve ark., 2012).

Olağan bir antrenman modeli esnasında her egzersiz pek çok kere tekrarlanmaktadır. Ancak farklılıkla öğrenme yönteminde ise her egzersiz kendi içinde farklı değişkenlere sahiptir. Schöllhorn, tekrarlanan ve ideal koşullar altındaki hareket örgüsünün tekrarlanmasından ziyade, koşulların değişken olmasının öğrenme üzerinde daha etkili olacağını savunmuştur. Aslında farklılıkla öğrenme yöntemi sporcuyu öngörülemeyen hareketlerin yaşanacağı gerçek oyuna hazırlamaktadır (Schöllhorn 
ve ark., 2010; Schöllhorn ve ark., 2012; Tallır ve ark., 2012). Buna ek olarak spor, dinamik doğrusal olmayan sistemler olduğundan beceri öğrenmesi de doğrusal olmamalıdır (Chow ve ark., 2007).

Geleneksel "kapalı" eğitim antrenmanlarının değişkenlik eksikliği, oyuncuların hareket örgülerini değişen çevresel taleplere nasıl uyarlayabileceklerini çözümleme fırsatını azaltır. Geleneksel antrenman yöntemiyle düzenlenmiş antrenmanlar, oyuncuların artan hassasiyet ve düşük hata ile yeteneklerini geliştirmelerine olanak veren basitleştirilmiş bir ortam sunarken, değiştirilmiş oyunlar, oyuncuların yeteneklerinin yerine, rakiplerinin yerleri gibi fonksiyonel ve verimli algısal değiş̧kenlerle yeteneklerini daha iyi kalibre etmeleri için bir firsat sunar. (Passos ve ark., 2008). Ayrıca farklılıkla öğrenme yönteminde sporcu değişken koşulların yardımı ile alışılagelmiş motor becerilerinde dalgalanma sağlayarak bireysel hareket ve öğrenme becerisini geliştirme olasıllğg bulmaktadır. Hareket tekrarının kısıtlanması ve işlevsel olarak göreve özgü davranışlara olan uyumunun kuvvetlenmesi farklılıkla öğrenme yönteminin tipik özelliklerindendir. Antrenman süreci esnasında değişken koşullar sayesinde sporcu harekete özgü tekniğinin mükemmel uygulanmasına değil, harekete özgü tekniğin temeline ve değişkenliğine odaklanmaktadır. Bu sayede sporcu, oyun içerisinde farklı değişkenler olsa bile daha iyi performans gösterebilmektedir (Smith, 2014).

Diferansiyel öğrenme yaklaşımı, karmaşık bir sistemdeki dalgalanmalardan, "tekrarlama yok" ve stokastik bozulmalar ekleyen "sürekli değişen hareket görevlerini" kullanmayı artırarak faydalanır. Önceki araştırmalar tek hareket tekniklerini öğrenmek için, tekrarlama ve düzeltme yaklaşımları ile karşılaştırıldığında, farklı bir öğrenme yaklaşımının üstünlüğüne dair birçok kanıt sağlamıştır. Doğrusal olmama üzerine inşa edilen diferansiyel öğrenme, hareket tekrarını sınırlayarak uyarlanabilir ve işlevsel göreve özgü davranışları teşvik etmekle karakterize edilir (Schöllhorn ve ark., 2009). Bu anlamda, oyuncuların görev performansındaki değişkenlikle ilgili mükemmel teknik uygulamaya odaklanmak yerine yeni hareket çözümlerini keşfetmeleri teşvik edilmektedir (Schöllhorn ve ark., 2012).

Günümüzde takım sporları büyük öngörülemezlik, yüksek karar alma talepleri ve çok çeşitli oyuncularla karakterize edilir. Bu şartlar altında, oyuncuların rekabetçi ortamlar tarafından dayatılan tüm olumsuzlukların üstesinden gelmek için fiziksel, teknik ve taktik kapasitelerinin üstünde olmaları gerekir. Bu nedenle, antrenörler farklı görevlerle motorsal, algısal ve bilişsel kapasiteleri geliştirebilmeleri gerekmektedir (Haudum ve ark., 2012). Bu bağlamda, takım sporlarında veya elit sporcularda fiziksel okuryazarlık önemli bir etken olarak göze çarpmaktadır. Fiziksel okuryazarlık, birinin yaşamı boyunca fiziksel aktiviteyi sürdürmek için gereken motivasyon, güven, fiziksel yeterlilik, bilgi ve anlayış olarak tanımlanabilir (Longmuir ve ark., 2015). Bunlara ek olarak, motor alanı ile ilgili olarak, fiziksel okuryazarlık eğitimi takım sporlarında yoğun bir şekilde kullanılmaktadır (Giblin ve ark., 2014). Fiziksel okuryazarlığı geliştirmek adına, farklılıkla öğrenme yöntemi içeren çalışmalarda olduğu gibi, birden fazla spor aktivitesine katılım, fiziksel okuryazarlı̆̆ 1 beslemektedir (Côté ve Vierimaa, 2014). Ayrıca temel motor beceriler lokomotif, manipülatif ve stabilizasyon becerilerinin ustalığını benimserken, temel oyun becerileri, oyuncuların oyun sırasında takım arkadaşlarının ve rakiplerinin pozisyonlarına göre kullanmaları gereken özel ve karmaşık spor becerilerini içerir (Jaakkola ve ark., 2016; Lubans ve ark., 2010). Bu nedenle fiziksel okuryazarlığı ve 
temel motor becerilerin eğitimi, oyunla ilgili bir performansı arttırmada faydalı olabilir. (Faude ve ark., 2012; Scanlan ve ark., 2014).

Çağdaş takım sporlarındaki sporcular, erken çocukluk dönemine özel katılımla karakterize edilen ve mevcut rekabetçi taleplerin yanıtı olarak yüksek derecede yapılandırılmış eğitimi teşvik eden yollar ile geliştirilmelidir. (Baker ve ark., 2003). Bununla birlikte, oyun zorluklarının üstesinden gelmek için hareket düzenlerinde uyarlama ve değişiklik yapma ile ilgili yeni yollar oluşturma konusunda ilham vermek, eğitim süreçlerinin önemli bir yönüdür (Chow ve ark., 2015; Santos ve ark., 2016).

Diferansiyel öğrenme yöntemiyle kurgulanmış çalışmalar basketbol oyuncuları için önemlidir; çünkü ayak oyunları becerilerinin düzgün bir şekilde gelişmesini destekler. Böylece, yüksek motor yeteneğine sahip bir oyuncu fiziksel olarak zorlu durumlarda başarı olasılığını arttırır. Bunun nedeni, sporcuların çevre koşullarını daha fazla analiz edebilmesi, tahmin etmesi veya öncellemesi, daha uygun bir şekilde tepki vermesidir (Higgs, 2010). Ayrıca basketbol, fiziksel okuryazarlık eğitiminin temeli olarak kabul edilen temel motor becerilerin ve temel oyun becerilerinin uygun bir şekilde geliştirilmesine bağlı olan çoklu becerilerde ustalık gerektirmektedir (Smith, 2014).

\section{Alanda Yapılan Çalışmalar}

Diferansiyel öğrenme çalışmaları, sistem uyumluluğunu ve dinamiklerini değiştirerek denekleri uyum sağlama yanıtı keşfetmeye zorlayan yeni bir deneyim seti sağlamaktadır (Torrents ve ark., 2007). Diferansiyel öğrenme felsefesi: "doğru oynamak için asla doğru şeyi uygulama” dır (Schöllhorn ve ark., 2004). Bu bilgilere dayanarak Santos ve ark. (2017) tarafından yapılan bir çalışmada farklılıkla öğrenme yönteminin etkileri araştırılmıştır. Çalışma esnasında farklı düzeyde spor bilgisine sahip 20-22 yaş aralığında 76 tane üniversite öğrencisi kullanılmış ve spor bilgi seviyelerine göre (anket sonucu) erken yaşta, geç yaşta uzmanlaşanlar ve yapılandırılmamış spor deneyimlerine göre üç grup altında değerlendirilmiştir. 76 denek rastgele kontrol grubu ve deney grubu olarak ayrılmıştır. Çalışma esnasında her iki gruba da haftada iki gün ikişer saat antrenman sekiz hafta boyunca yaptırılmıştır. Kontrol grubuna geleneksel öğrenme yöntemine göre oluşturulmuş antrenman programı uygulanırken, deney grubu farklılıkla öğrenme yöntemi ile oluşturulmuş zenginleştirilmiş antrenman programı takip ettirilmiştir. Test protokolü olarak çeviklik ölçümü için Illinois Agility Test, pas verme, şut atma ve top hakimiyeti ölçümü için Taco Bell yetenek testi kullanılmıştır. Bu testlere ek olarak dörde dört tam saha basketbol oyunlarında takım içindeki oyuncuların becerileri de değerlendirilmiştir. Araştırmanın sonunda, deney grubunun özellikle anlık karar vermek becerisinde anlamlı bir artış ve geç uzmanlaşan gruba ait olan deneklerde farklılıkla öğrenme yönteminin temel basketbol taktik prensiplerini daha kolay benimsettiği tespit edilmiştir. Ayrıca denek grubunun yapılan Illinois çeviklik testi sonuçlarına dayanarak gösterdiği başarı farklılıkla öğrenme yönteminin çeviklik antrenmanları için bir alternatif olabileceği gösterilmiştir (Santos ve ark., 2017). Alpullu ve Bozkurt tarafından 2018 yılında basketbol branşında yapılan başka bir çalışmada ise Marmara Üniversitesi Spor Okulu bünyesindeki 10-12 yaş aralığındaki 23 öğrenci, kontrol ve deney grubu olmak üzere rastgele iki gruba ayrılmıştır. Her iki gruba da sekiz hafta boyunca haftada 120 dakikalık 
antrenman periyodunun 10-15 dakikasında basketbola özgü farklılıkla öğrenme yöntemine göre oluşturulmuş antrenman programı takip ettirilmiştir. 13 yaş altı basketbolcularda farklılıkla öğrenme yönteminin etkileri Heidelberger Basketbol Testi Protokolüne göre değerlendirmiştir. Araştırma sonucunda, deney grubunda bulunan oyuncularda bütün teknik becerilerde anlaml bir artı̧ ( $\mathrm{p}<0.05)$ olduğu tespit edilmiştir (Alpullu ve Bozkurt, 2018). Bunu destekleyen başka bir çalı̧̧mada ise Tallir ve ark. (2012) farklılıkla öğrenmenin etkilerini 11-12 yaş aralığında 42 tane altyapı oyuncusu üzerinde değerlendirmişlerdir. Yapılan ön testler ile basketbol becerilerine beşten ona kadar puan verilmiştir. Değerlendirmeler esnasında sadece 30 oyuncu kullanılmıştır. Çalışma esnasında, eşit beceri puanlarına sahip olan takımlar eşleştirilerek beşe beş ve bir hafta sonrasında farklılıkla öğrenme sağlamak amacı ile üçe üç maçlar yaptırılmıştır. Beşe beş oynanan maçlardaki saha ölçüleri 14m x 26m olarak kullanılırken üçe üç yapılan maçlarda saha ölçüleri 14m x 13m olarak belirlenmiştir. Analiz sonucunda, üçe üç oyun performansı çıtılları ile beşe beş oyun performans çıktıları arasında karar alma, motor becerileri uygulama ve motor uygulama etkinliği değiş̧kenlerinde anlamlı farklılıklar tespit edilmiştir. Farklılıkla öğrenme sağlayan üçe üç oyunların değişkenler üzerinde daha olumlu etkileri olduğu gösterilmiştir (Tallır ve ark., 2012).

Yapılan antrenmanların oyun performansına direkt olarak pozitif bir şekilde yansımasını sağlayacak olan en uygun yöntem konusunda tartışmalar devam etmektedir. Yukarıda özetlenmiş olarak farklı çalışma gruplarınca yapılmış olan karşılaştırmalar sonucunda farklılıkla öğrenmenin özellikle çeviklik gibi motor beceriler ve oyun esnasında farklı değişkenlerle karşılaşan sporcuların performansları üzerinde olumlu etkiler gösterdiği tespit edilmiştir. Ayrıca farklılıkla öğrenme yönteminin kullanıldığı antrenman periyodları sonucunda oyun esnasında yapılan teknik hatalarda azalma olduğu gösterilmiştir.

Çoğu basketbol koçu, sporcuların serbest atış kullanması için belirlenmiş bir rutin üzerine yoğunlaşmakta ve oyuncuların müsabaka esnasında bu rutinden sapmamalarını istemektedir (Reinhart, 1981; Sanderford ve Shoenfelt, 2001). Bu olağan görüşe alternatif olarak Shonfelt ve ark. 2002 yılında basketboldaki serbest atışın değişken ve sabit durumlarda kullanılmasının karşılaştırılması üzerine bir çalışma yapmışlardır. Bu çalışmaya orta büyüklükteki bir güneydoğu üniversitesindeki yaş ortalaması 20.1 olan 64 erkek ve 30 kadın katılmıştır ve katılımcılarda basketbol geçmişi deneyimi aranmamıştır. Katılımcılara basketboldaki serbest atış tekniği anlatıldıktan sonra istatiksel veriler kullanılarak kişilerin seviyeleri toplamda 40 atıştan oluşan bir ön test ile belirlenmiştir ve katılımcılar Sabit, Değişken Ön ve Arka, Değişken Kombinasyon ve Değişken Rastgele olmak üzere 4 farklı deney grubu olarak rastgele dağıtılmıştır. Bu sürecin tamamlanmasının ardından, her grup 3 hafta boyunca salı gününden cuma gününe kadar haftada dört gün 40 atış olmak üzere egzersiz yapmışlardır. $\mathrm{Bu}$ gruplardan "sabit grup" olarak adlandırılanlar çalışma süresince klasik basketbol faul atışı yaparken, diğer gruplar faul atış çizgisinin farklı yerlerinden atış kullanmışlardır ve katılımcılar her hafta birer kez toplamda 3 hafta olmak üzere 40 atışlı faul atışı testlerine girmişlerdir. Çalışmanın sonunda katılımcılar \%5.2' lik bir serbest atış gelişim göstermiştir. Ayrıca bu gelişim bir basketbol maçının kaderini belirleyecek kadar iyi olduğu vurgulanmıştır. Çalışmada sabit grup olarak adlandırılan ve müsabakadaki gibi serbest atış atan grup diğer üç grupla karşılaştırıldığında daha iyi bir performans sergilememiştir (Shoenfelt ve ark., 2002). 
Santos ve arkadaşlarının 2015 yılında yaptığı başka bir çalışma ise fiziksel okur yazarlık ve farklılıkla öğrenmenin motor beceriler ve basketboldaki teknik becerilerine etkisi üzerine olmuştur. Çalışmada 20-22 yaş aralığındaki yetmiş altı üniversite öğrencisi kontrol ve deney grubu olmak üzere 2 gruba rastgele dağıtılmıştır. Motor becerilerin test edilmesinde Ilinois çeviklik testi, basketbol teknik becerilerinin (pas verme, şut atma ve dribling) test edilmesinde ise "Taco Bell” basketbol yetenek yarışmasını test protokolü olarak kullanmışlardır. Aynı zamanda bununla birlikte deneklere dörde dört tam saha basketbol oynatıp, basketbolun oyun içeriğini oluşturan üçlü tehdit, iki sayılık atışlar, bire bir oyun, pas ver ve git gibi parametreleri kameralar aracılığıyla takip ederek başarılı ve başarısız eylemler olmak üzere değerlendirmişlerdir. Çalışmanın sonunda Santos ve arkadaşları çeviklik son testinde ön teste oranla anlamlı fark $(\mathrm{p}<0.05)$ bulmuşlardır. Bununla birlikte tüm oyun becerilerindeki başarısız eylemlerde belirgin azalma gözlemlenmiş ve özellikle üçlü tehdit ve pas ver ve git parametrelerindeki iyileşmelere dikkat çekmişlerdir (Mateus ve ark., 2015).

Tüm bu bilgilerin ışı̆̆ında, farklılıkla öğrenme yönteminin verimliliği 16-18 yaş aralığında bulunan basketbol oyuncuları üzerinde denenmiştir. Aynı yaş grubundaki basketbol oynayan müsabaka tecrübesi yüksek sporcular üzerinde yapılmış farklılıkla öğrenme yönteminin kullanıldı̆̆ çalışmaya literatürde rastlanmamıştır.

\section{GEREÇ VE YÖNTEM}

16-18 yaş aralığındaki, $88 \mathrm{~kg}$. vücut ağırlığı ve $1,88 \mathrm{~m}$ boy ortalamasına sahip, haftada altı gün düzenli antrenman yapan ve müsabakalara katılan UPS Spor ve Kültür Kulübü Yarışmacı Basketbol Genç takımı oyuncuları gönüllü olarak bu çalışmada yer almıştır. Çalışmaya katılan sporcuların deneyim düzeyleri 4-7 yıl seviyesindedir. Araştırma için UPS Spor ve Kültür Kulübü’ nden izin alınmıştır. Ayrıca sporculara ve çalışmada yer alan 18 yaş altı sporcular için velilerinden ayrıca izin alınmıştır. Çalışma esnasında German Heidelberger Basketball Test (turnike testi, top sürüş testi, şut testi, pas testi) esas alınmıştır. Çalışmada 24 erkek sporcu yer almıştır. Çalışmamız Ups Spor ve Kültür Kulübü Zeytinburnu’ ndaki tesislerindeki basketbol sahasında yapılmıștır. Çalışmadaki veriler top sürme testi süre baz alınarak yapıldığından kronometre ile, pas verme, şut atma ve turnike testleri puanlama esas alınarak sporcular için hazırlanan veri toplama formuna kaydedilmiştir.

Oyuncular 12' şer kişilik kontrol grubu ve deney grubu olarak ayrıldıktan sonra ön teste tabii tutulmuştur. Ön test sonrası kontrol grubu haftada altı gün olağan basketbol antrenmanları takip ettirilirken, deney grubunda yer alan sporculara haftada dört gün farklılıkla öğrenme yöntemiyle zenginleştirilmiş basketbol antrenman programı takip ettirilmiş diğer iki gün ise olağan basketbol antrenmanlarına devam etmişlerdir. Deney grubuna ve kontrol grubuna yaptırılan antrenmanlar her iki grubunda bağlı olduğu genç takım kategorisinin baş antrenörü Murat Özçelik tarafından yaptırılmıştır. Deney grubuna yaptırılan antrenmanlar dört gün pazartesi, salı, çarşamba ve perşembe olmak üzere yaptırılmıştır. Geriye kalan iki gün, cuma ve cumartesi günleri olağan antrenmanlara devam edilmiştir. Kontrol grubu ise altı gün boyunca olağan antrenman süreçlerine 
devam etmişlerdir. Kontrol grubuna yaptırılan geleneksel basketbol antrenmanları, çok tekrarlı yapılan hareketin formunu mükemmelleştirmek amacıyla sporculara hareketin aynısını uygun koşullar altında yapmalarına izin verilen basketbol antrenman programı uygulanmıştır. Deney grubunun antrenmanları saat 18:00' da olurken akabinde kontrol grubunun antrenmanları saat 19:30' da yaptırılmıştır.

\section{German Heidelberger Basketbol Testi}

Heidelberger Basketbol testi 1987 yllında Heidelberg' de bulunan Spor Enstitüsü bilim insanları ve basketbol antrenörlerinin birlikte çalışması sonucu ortaya çıarılmıştır. Testin etkinliği, performans seviyelerinin ve performans değişikliklerinin güncel teşhisiyle birlikte gelişiminin değerlendirilmesi ve eğitimin araştırma amaçlı süreçlerinin belirlenmesidir. Ayrıca test, birinci basamak seviyesinde düzenlenmiş olup güçlü ve zayıf kondisyon ve teknik uygulamasının gösterimidir. Böyle bir testin uygulanmasında antrenman bir ölçü alınarak etkisi ölçülebilir (Bös, 1987; Alpullu, 2015).

Bu test kondisyon ve teknik olmak üzere iki ana bölümden oluşmaktadır. Çalışma esnasında sadece teknik faktörlerin değerlendirmesi yapılmıştır.

\section{Teknik Test Uygulaması}

Alt test olan "Teknik" testlerin dinlenme süreleri, ikinci denemeye başlarken 2 ile $3 \mathrm{dk}$. arasında uygulanmalı ve $45 \mathrm{dk}$. sürmektedir.

\section{TI Turnike}

İlk önce sağ sonra sol turnike atılır. Her atılan turnikede top serbest atış çizgisine kadar sektirilir. 1 dk. içerisinde basket olan turnikeler değerlendirilir. Her bir turnike sonunda basket olan turnikeler 1 puan olarak sayllır. Her deneme periyodu için 2 değerlendirme alınır (Bös, 1987; Alpullu, 2015).

\section{T2 3 saniye koridorunun dışından şut atma}

Şut atılacak bölgeler eşit şekilde 4' e ayrılarak yerleri bir bant ya da trafik hunisi ile belirlenir. Eşitleme şu şekilde yapılır; faul çizgisinin tam ortasından üç sayılık çizgisine kadar ve dip çizgisinden 2 metre, üç saniye koridoru çizgisinde üç sayllık çizgisine paralel çizgi çizilir.

Hazır ol komutu ile oyuncu dört bölge olan dip taraftan başlar. Düdük komutu ile durarak veya sıçrayarak atış yapmaya başlar ve ardından kendi topunu takip ederek kendi reboundunu alır. Reboundu aldıktan sonra topu ikinci bölgeye sürer ve atışını yapar. $1 \mathrm{dk}$. içerisinde çemberden geçen top sayı kabul edilir. Her oyuncu için en iyi iki deneme sonucu kayıt edilir. Üç saniye koridoru içinden yapılan atışlar geçersiz sayılır. Aynı bölgeden tekrar atış hakkı yoktur. Çemberden geçen top 1 puan sayılır (Bös, 1987; Alpullu, 2015). 


\section{T3 Slalom top sürme}

10 adet slalom çubukları hazırlanır. Birbirleri ile aralarında şu mesafeler dikkate alınır. Çıkış pozisyonundan itibaren $2 \mathrm{~m}-1 \mathrm{~m}-1 \mathrm{~m}-2 \mathrm{~m}-1 \mathrm{~m}-1 \mathrm{~m}-4 \mathrm{~m}-1 \mathrm{~m}-1 \mathrm{~m}$ aralıklarla çubuklar yerleştirilir. Çubuklar arasında top sektirme için dikkat edilmesi gereken noktalar şunlardır; top sektirilirken çubuklar arasında el değiştirilir ve sporcuların sağ el ile başlanırken çubuğun sağ tarafına doğru yönlenmeleri gerekir. Bu uygulama için gidiş-geliş süreleri kronometre aracılığ1 ile tutulur. Her oyuncuya 3 deneme hakkı verilerek en kısa süreli zaman kayda alınır (Bös, 1987; Alpullu, 2015).

\section{T4 Pas testi}

Duvar üzerine bant yardımı ile $30 \mathrm{~cm}$ uzunluğunda kare oluşacak biçimde iki adet dörtgen oluşturulur. İki dörtgenin orta noktası birbirinden 1,80m uzunluğundan ayrı ve yerden yüksekliği 1,50m olacak şekilde düzenlenir. Duvardan 2m mesafe olacak şekilde salon zeminine $1 \mathrm{~m}$ bant çekilir. Başlangıç çizgisi kenarlarında iki adet çubuk bulunmaktadır. Araları $1 \mathrm{~m}$ komut ile hedefe topu atarak geri alır ve topu alır almaz dış el ise diğer çubuğun yanına topu sürer. Oyuncu mümkün olduğu kadara hızlı olmalıdır. 30 sn. içinde mümkün olduğu kadar çok isabet elde etmesi gerekmektedir. Her oyuncunun deneme şansı bulunmaktadır. 30 saniye içerisinde isabetli atışları sayılmaktadır. 1 puana ulaşma ancak hedefin çizgisine veya içine değdiğinde ulaşılır. İki denemenin sonunda en iyi değer alınır. Sayıyı sayan kişi hedefin tam karşısında ve oyuncunun arkasında isabetli atışları saymalıdır (Bös, 1987; Alpullu, 2015).

Tablo 1. Heidelberger basketbol testi değerlendirme kriterleri

\begin{tabular}{llll}
\hline & Kötü & Orta & İyi \\
\hline Turnike & -12 & $13-14$ & $15+$ \\
Şut & -13 & $14-16$ & $17+$ \\
Top sürme & -14.8 & $14.7-13.3$ & $13.2+$ \\
Pas verme & -19 & $20-21$ & $22+$ \\
\hline
\end{tabular}

*(Bös, 1987; Alpullu, 2015).

Çalışmamızda Heidelberger basketbol testi, ön test ve son test olarak uygulanmıştır. Ön testin ardından sporculara sekiz haftalık farklılıkla öğrenme yöntemi içeren antrenmanlar yaptırılmıştır. $\mathrm{Bu}$ antrenmanların içeriği her bir parametre için farklılıklar oluşturmaktadır.

Aşağıda sekiz hafta boyunca, haftada 4 gün uygulanmış antrenman programının örneği bulunmaktadır. $\mathrm{Bu}$ antrenman, basketbola özgü ısınma bölümünün ardından antrenmanın ana bölümünde sporculara yaptırılmıştır ve uygulama her beceri dalından iki kısım seçilerek beş dakikalık çalışmalar halinde toplamda 20 dakika olarak belirlenmiştir. (Bös, 1987; Alpullu, 2015). 
Tablo 2. Farklılıkla öğrenme yöntemine göre hazırlanmış antrenman programı

\begin{tabular}{|c|c|}
\hline Ana Bölüm & \\
\hline & Çift top turnike atma \\
\hline & Farklı spor dallarının topları ile turnike atma (hentbol-tenis topu) \\
\hline Turnike & Tek göz kapalı turnike atma \\
\hline & Ağırlık topu ile turnike atma \\
\hline & Uzak mesafeden turnike atma \\
\hline & $\begin{array}{l}\text { Çift top ile top sürme kombinasyonları (slalom-önden yön değiştirme-arkadan yön değişme- } \\
\text { bacak arası yön değiştirme-duvarda sektirme-tek elle sektirirken diğer elle tenis topunu yukarı firlatma) }\end{array}$ \\
\hline & Tek top yumruk ile top sektirme \\
\hline Top Sürme & Tenis topu ile top sektirme \\
\hline & Bir göz kapalı top sektirme \\
\hline & Balonu yere düşürmeden tek el top sektirme \\
\hline & Farklı spor dallarının toplarını aynı anda sektirme (hentbol topu ve basketbol) \\
\hline & Çift top ile duvara farklı biçimlerde pas verme (yerden sektirerek-göğüs pası-aşırtma pas) \\
\hline & - $\quad$ Çift top eş ile farklı biçimlerde paslaşma (tek top ile sektirerek tek el paslaşma-çift top dire \\
\hline & paslaşma) \\
\hline Pas Verme & $\begin{array}{l}\text { Farklı spor branşlarının topları ile paslaşma (basketbol topu sektirirken tenis topu veya ağırlık } \\
\text { topları ile paslasma) }\end{array}$ \\
\hline & 5'e 5 pas maçı (farklı spor dallarının topu ile) \\
\hline & 4'e 4 pas oyunları \\
\hline & Tek göz kapalı şut atma \\
\hline & Tek ayak siçrayarak şut atma \\
\hline & Tek ayak üstünde 360 derece dönüp şut atma \\
\hline Şut Atma & Siçramadan şut atma \\
\hline & Tek elle şut atma \\
\hline & Uzak mesafeden şut atma (yarı saha) \\
\hline
\end{tabular}

*(Santos, 2017; Alpullu, 2015; Tallir, 2012).

\section{İstatiksel Analiz}

Betimleyici istatistikler; aritmetik ortalama (Ort.), standart sapma (SS), minimum (Min.) ve maksimum (Maks.) olarak sunulmuştur. Grupların ön ve son testlerinin karşılaştırılmasında Wilcoxon testi ve kontrol ve deney grubunun arasındaki anlamlı farkın bulunması için T testi kullanılmıştır. p' nin 0.05 ' ten küçük olması durumunda bir sonucun anlamlı olduğu kabul edilmiştir. Bu çalışmanın istatistiki ölçümleri SPSS Statistics 23.0 programında yapılmıştır. 


\section{BULGULAR}

Tablo 3. Farklılıkla Öğrenme Antrenmanları Uygulanmamış (Kontrol Grubu) Oyuncuların Betimleyici İstatiksel Değerleri

\begin{tabular}{llllll}
\hline & & Ort. & SS & Min. & Maks. \\
\hline \multirow{2}{*}{ Turnike(puan) } & Ön Test & 13,08 & 1,73 & 11 & 17 \\
\cline { 2 - 6 } & Son Test & 13,75 & 1,82 & 11 & 16 \\
\hline Dribling(sn.) & Ön Test & $13,95^{\prime}$ &, 66 & $13,10^{\prime}$ & $15,80^{\prime}$ \\
& Son Test & $13,93^{\prime}$ &, 72 & $13,07^{\prime}$ & $15,93^{\prime}$ \\
\hline Pas Verme (puan) & Ön Test & 18,25 & 1,49 & 15 & 20 \\
& Son Test & 18,75 & 1,49 & 15 & 20 \\
\hline Şut Atma (puan) & Ön Test & 8,33 & 2,77 & 4 & 13 \\
& Son Test & 8,17 & 2,48 & 5 & 13 \\
\hline
\end{tabular}

Geleneksel öğrenme yöntemi antrenmanlarıyla çalışılan kontrol grubunun turnike, top sürme, şut atma ve pas verme ölçümlerinin ön test ve son test analizlerinin betimleyici istatistikleri Tablo 3' te gösterilmiştir.Uygulanan testler ve oyuncuların ön test ve son test sonuçlarının ortalama değerleri: turnike testi (ön test: $13,08 \pm 1,73$ puan, son test: 13,75 $\pm 1,82$ puan), top sürme testi (ön test: 13,95 \pm 0,66 saniye, son test: 13,93 \pm 0,72 saniye), pas verme testi (ön test: $18,25 \pm 1,49$ puan, son test: $18,75 \pm 1,49$ puan), şut atma testi (ön test: $8,33 \pm 2,77$ puan, son test: $8,17 \pm 2,48$ puan).

Tablo 4. Wilcoxon Analiz Testine Göre Farklılıkla Öğrenme Antrenmanları Uygulanmamış (Kontrol Grubu) Oyuncuların İstatiksel Değerleri

\begin{tabular}{|c|c|c|c|c|c|}
\hline & & Ort. & SS & $\mathrm{Z}$ & $\mathrm{p}$ \\
\hline \multirow{2}{*}{ Turnike (puan) } & Ön Test & 13,08 & 1,73 & \multirow{2}{*}{$-1,469$} & \multirow{2}{*}{, 142 } \\
\hline & Son Test & 13,75 & 1,82 & & \\
\hline \multirow{2}{*}{ Dribling (sn.) } & Ön Test & $13,95^{\prime}$ & ,66’ & \multirow{2}{*}{,- 079} & \multirow{2}{*}{,937 } \\
\hline & Son Test & $13,93^{\prime}$ & ,57' & & \\
\hline \multirow{2}{*}{ Pas Verme puan) } & Ön Test & 18,25 & 1,49 & \multirow{2}{*}{$-1,730$} & \multirow{2}{*}{, 084} \\
\hline & Son Test & 18,75 & 1,49 & & \\
\hline \multirow{2}{*}{ Şut Atma (puan) } & Ön Test & 8,33 & 2,77 & \multirow{2}{*}{,- 466} & \multirow{2}{*}{,641 } \\
\hline & Son Test & 8,17 & 2,48 & & \\
\hline
\end{tabular}


Çalışmadaki kontrol grubunun turnike, top sürme, şut atma ve pas verme ölçümlerinin Wilcoxon testine göre ön test ve son test analizleri Tablo 4' te gösterilmiştir. Geleneksel öğrenme yöntemi antrenmanlarıyla çalışılan kontrol grubunda; turnike $(Z=-1,469, p=0.142)$, top sürme $(Z=-0,79$, $\mathrm{p}=0.937)$, pas verme $(Z=-1,730, \mathrm{p}=0.084)$ ve şut atma $(Z=-0,466, \mathrm{p}=0,641)$ performanslarında ön test ve son testler arasında anlamlı farklılık bulunamamıştır ( $\mathrm{p}>0.05)$.

Tablo 5. Farklılıkla Öğrenme Antrenmanları Uygulanmış (Deney Grubu) Oyuncuların Betimleyici İstatiksel Değerleri

\begin{tabular}{llllll} 
& & Ort. & SS & Min. & Maks \\
\hline \multirow{2}{*}{ Turnike(puan) } & Ön Test & 13,42 & 1,73 & 11 & 17 \\
\cline { 2 - 6 } & Son Test & 15,67 & 1,07 & 14 & 17 \\
\hline \multirow{2}{*}{ Dribling(sn.) } & Ön Test & $13,19^{\prime}$ &, $62^{\prime}$ & $12,20^{\prime}$ & $13,99^{\prime}$ \\
\cline { 2 - 6 } & Son Test & $13,05^{\prime}$ &, $54^{\prime}$ & $12,18^{\prime}$ & $13,76^{\prime}$ \\
\hline \multirow{2}{*}{ Pas Verme(puan) } & Ön Test & 20,25 & 1,14 & 18 & 22 \\
\cline { 2 - 6 } & Son Test & 21,33 & 1,23 & 19 & 23 \\
\hline \multirow{2}{*}{ Şut Atma(puan) } & Ön Test & 9,83 & 2,08 & 7 & 13 \\
\cline { 2 - 6 } & Son Test & 12,75 & 2,63 & 10 & 17 \\
\hline
\end{tabular}

Çalışmada gerçekleştirilen farklılıkla öğrenme deney grubunun turnike, top sürme, şut atma ve pas verme ölçümlerinin ön test ve son test analizlerinin betimleyici istatistikleri Tablo 5 ' te gösterilmiştir. Uygulanan testler ve oyuncuların ön test ve son test sonuçlarının ortalama değerleri: turnike testi (ön test: $13,42 \pm 1,73$ puan, son test: $15,67 \pm 1,07$ puan), top sürme testi (ön test: $13,19 \pm 0,62$ saniye, son test: $13,05 \pm 0,54$ saniye), pas verme testi (ön test: $20,25 \pm 1,14$ puan, son test: $21,33 \pm 1,23$ puan), şut atma testi (ön test: 9,83 $\pm 2,08$ puan, son test: $12,75 \pm 2,63$ puan).

Tablo 6. Wilcoxon Analiz Testine Göre Farklılıkla Öğrenme Antrenmanları Uygulanmış (Deney Grubu) Oyuncuların İstatiksel Değerleri

\begin{tabular}{|c|c|c|c|c|c|}
\hline & & Ort. & SS & $\mathrm{Z}$ & $\mathrm{p}$ \\
\hline \multirow{2}{*}{ Turnike (puan) } & Ön Test & 13,42 & 1,73 & \multirow{2}{*}{$-2,958$} & \multirow{2}{*}{, 003} \\
\hline & Son Test & 15,67 & 1,07 & & \\
\hline \multirow{2}{*}{ Dribling (sn.) } & Ön Test & $13,18^{\prime}$ & $13,18^{\prime}$ & \multirow{2}{*}{$-2,555$} & \multirow{2}{*}{, 011} \\
\hline & Son Test & $13,05^{\prime}$ & $13,05^{\prime}$ & & \\
\hline \multirow{2}{*}{ Pas Verme (puan) } & Ön Test & 20,25 & 1,14 & \multirow{2}{*}{$-2,410$} & \multirow{2}{*}{, 016} \\
\hline & Son Test & 21,33 & 1,23 & & \\
\hline \multirow{2}{*}{ Şut Atma (puan) } & Ön Test & 9,83 & 2,08 & \multirow{2}{*}{$-2,958$} & \multirow{2}{*}{, 003} \\
\hline & Son Test & 12,75 & 2,63 & & \\
\hline
\end{tabular}

Çalışmadaki farklılıkla öğrenme deney grubunun turnike, top sürme, şut atma ve pas verme ölçümlerinin Wilcoxon testine göre ön test ve son test analizleri Tablo 6 ’ te gösterilmiştir. 
Farklılıkla öğrenme antrenmanları uygulanan deney grubunda; turnike $(Z=-2,958, p=0.003)$, top sürme $(Z=-2,555, p=0.011)$, pas verme $(Z=-2,958, p=0.003)$ ve şut atma $(Z=-2,410, p=0,016)$ performanslarında ön test ve son testler arasında anlamlı farklılık bulunmuştur.

Tablo 7. Kontrol-Deney Grubu Arasındaki Anlamlı Farklılıkların Tespitinde Parametrik Olmayan Testlerden Man Whitney U “T Testi” Sonuçları

\begin{tabular}{llllll}
\hline & & Man Whitney U & Wilcoxon & Z & p \\
\hline \multirow{2}{*}{ Turnike (Sayı) } & Ön test & 62,500 & 140,500 &,- 567 &, 571 \\
\cline { 2 - 6 } & Son test & 27,500 & 105,500 & $-2,622$ &, 009 \\
\hline \multirow{2}{*}{ Dribbling (Zaman sn.) } & Ön test & 30,000 & 108,000 & $-2,426$ &, 015 \\
\cline { 2 - 6 } & Son test & 16,000 & 94,000 & $-3,235$ &, 001 \\
\hline \multirow{2}{*}{ Şut (Sayı) } & Ön test & 47,500 & 125,500 & $-1,432$ &, 152 \\
\cline { 2 - 6 } & Son test & 15,000 & 93,000 & $-3,310$ &, 001 \\
\hline \multirow{2}{*}{ Pas (Sayı) } & Ön test & 20,000 & 98,000 & $-3,103$ &, 002 \\
\cline { 2 - 6 } & Son test & 10,500 & 88,500 & $-3,618$ &, 000 \\
\hline
\end{tabular}

Çalışmada sınıflandırılmış kontrol ve deney grubunun beceri testleri arasında anlamlı farkı gösteren Man Whitney U testi verileri Tablo 7'de gösterilmiştir. Çalışmaya katılan deney ve kontrol grubunun arasındaki anlamlı farklılık için uygulanan Parametrik olmayan T testi (Man Whitney U) verileri, Turnike testi (ön test: 0,571) ( $\mathrm{p}>0.05)$., (son test: 0,009) ( $\mathrm{p}<0.05)$. Top sürme testi (ön test:0,15), (son test:0,001), ( $p<0.05)$. Şut atma testi (ön test: 0,152) ( $p>0.05)$, (son test: 0,001$)(p<0.05)$. Pas verme testi (ön test:0,002), (son test:0,000) $(\mathrm{p}<0.05)$.

Tablo 8. Kontrol-Deney Grubu Arasındaki Anlamlı Farklılıkların Tespitinde Parametrik Olmayan Testlerden T Testi" verileri

\begin{tabular}{|c|c|c|c|c|c|}
\hline & & $\mathrm{N}$ & Ortalama & S.S. & $\mathbf{p}$ \\
\hline \multirow{2}{*}{ Turnike (Ön Test) } & Deney grubu & 12 & 13,42 & 1,730 & \multirow{2}{*}{,- 571} \\
\hline & Kontrol grubu & 12 & 13,08 & 1,730 & \\
\hline \multirow{2}{*}{ Turnike (Son Test) } & Deney grubu & 12 & 15,67 & 1,073 & \multirow{2}{*}{,- 009} \\
\hline & Kontrol grubu & 12 & 13,75 & 1,815 & \\
\hline \multirow{2}{*}{ Dribbling (Ön Test) } & Deney grubu & 12 & 13,1858 & ,61688 & \multirow{2}{*}{ - 015} \\
\hline & Kontrol grubu & 12 & 13,9192 & ,67466 & \\
\hline \multirow{2}{*}{ Dribbling (Son Test) } & Deney grubu & 12 & 13,0500 &, 54372 & \multirow{2}{*}{,- 001} \\
\hline & Kontrol grubu & 12 & 13,9342 & ,72073 & \\
\hline \multirow{2}{*}{ Şut (Ön Test) } & Deney grubu & 12 & 9,83 & 2,082 & \multirow{2}{*}{,- 152} \\
\hline & Kontrol grubu & 12 & 8,33 & 2,774 & \\
\hline \multirow{2}{*}{ Şut (Son Test) } & Deney grubu & 12 & 12,75 & 2,633 & \multirow{2}{*}{,- 001} \\
\hline & Kontrol grubu & 12 & 8,17 & 2,480 & \\
\hline \multirow{2}{*}{ Pas (Ön Test) } & Deney grubu & 12 & 20,25 & 1,138 & \multirow{2}{*}{,- 002} \\
\hline & Kontrol grubu & 12 & 18,25 & 1,485 & \\
\hline \multirow{2}{*}{ Pas (Son Test) } & Deney grubu & 12 & 21,33 & 1,231 & \multirow{2}{*}{,- 000} \\
\hline & Kontrol grubu & 12 & 18,75 & 1,485 & \\
\hline
\end{tabular}


Çalışmada sınıflandırılmış kontrol ve deney grubunun beceri testleri arasında anlamlı farkı gösteren paratmetrik olmayan $\mathrm{T}$ testi verileri Tablo 8'de gösterilmiştir. Çalışmaya katılan deney ve kontrol grubunun arasındaki anlamlı farklılık için uygulanan Parametrik olmayan T testi verileri: Turnike testi deney grubu ortalamaları (ön test: 13,42, son test: 15,67), top sürme testi deney grubu ortalamaları (ön test 13,18, son test: 13,05), pas verme testi deney grubu ortalamaları (ön test: 20,25, son test: 21,33), şut atma testi deney grubu ortalamaları (ön test: 9,83, son test:12,75) olarak gösterilmiştir.

Turnike testi kontrol grubu ortalamaları (ön test: 13,08 son test: 13,75), top sürme testi kontrol grubu ortalamaları (ön test 13,91 son test: 13,93), pas verme testi kontrol grubu ortalamaları (ön test: 18,25 , son test: 18,75), şut atma testi kontrol grubu ortalamaları (ön test: 8,33, son test:8,17) olarak gösterilmiştir.

\section{TARTIŞMA VE SONUÇ}

$\mathrm{Bu}$ çalışmanın amacı, basketbol eğitimine devam eden ve resmi müsabakalara katılan 16-18 yaş aralığındaki yarışmacı genç takım basketbol oyunlarının farklılıkla öğrenme eğitiminin teknik gelişime olan etkisini incelemektir.

$\mathrm{Bu}$ çalı̧̧mada basketbolun temelini oluşturan dört beceri faktörü farklılıkla öğrenme teknikleri kullanılarak çalıştırılmıştır ve Heidelbelger basketbol test protokolü kullanılarak test edilmiştir. Oyuncular ( 24 erkek sporcu) bütün testi her beceri dalında tamamlayabilmişlerdir.

Çalışmaya katılan deney grubu sporcuları sekiz hafta boyunca haftada 4 gün farklılıkla öğrenme yöntemi kullanılarak çalıştırılmıştır. Çalışmasını yaptığımız farklılıkla öğrenme yöntemiyle zenginleştirilmiş antrenman programı, 1sınma bölümünün ardından 15-20 dakikalık bölümler halinde basketbol antrenmanlara eklenmiştir. Zenginleştirilmiş antrenman bölümünde, dört temel basketbol beceri kategorisinden ikişer çalışma (drill) seçilmiş ve her antrenmanda farklı çalışmalar uygulanmıştır (Tablo 2). Bu bölümün ardından ana bölümde olağan takım antrenmanlarına devam edilmiştir. Kontrol grubu olarak sinıfladığımız oyuncular ise sekiz hafta boyunca haftada altı gün olağan basketbol antrenmanları (geleneksel öğrenme yaklaşımı) kullanılarak çalıştırılmıştır.

\section{Değiş̧enler Arası Farklılıkların Araştırılması}

\section{Geleneksel Öğrenme Antrenmanlarının Kontrol Grubu Oyuncuları Üzerindeki Etkisi}

Wilcoxon analiz testine göre turnike, dribling(top sürme), pas verme ve şut atma beceri testleri performanslarında anlamlı bir farklılık bulunamamıștır $(\mathrm{p}>0.05)$.

$\mathrm{H}_{0 \mathrm{~A} 1}$ : Geleneksel öğrenme antrenmanları uygulanan kontrol grubundaki 16-18 yaş aralığındaki yarışmacı genç takım oyuncularının turnike performanslarının ön test ve son testleri arasında $\alpha=0.05$ düzeyinde anlamlı bir farklılık yoktur. $\mathrm{H}_{0 \mathrm{~A} 1}$ hipotezi kabul edilmiştir. 
$\mathrm{H}_{0 \mathrm{~A} 2}$ : Geleneksel öğrenme antrenmanları uygulanan kontrol grubundaki 16-18 yaş aralığındaki yarışmacı genç takım oyuncularının dribling performanslarının ön test ve son testleri arasında $\alpha=0.05$ düzeyinde anlamlı bir farklılık yoktur. $\mathrm{H}_{0 \mathrm{~A} 2}$ hipotezi kabul edilmiştir.

$\mathrm{H}_{0 \mathrm{~A} 3}$ : Geleneksel öğrenme antrenmanları uygulanan kontrol grubundaki 16-18 yaş aralığındaki yarışmacı genç takım oyuncularının pas verme performanslarının ön test ve son testleri arasında $\alpha=0.05$ düzeyinde anlamlı bir farklılık yoktur. $\mathrm{H}_{0 \mathrm{~A} 3}$ hipotezi kabul edilmiştir.

$\mathrm{H}_{0 \mathrm{~A} 4}$ : Geleneksel öğrenme antrenmanları uygulanan kontrol grubundaki 16-18 yaş aralığındaki yarışmacı genç takım oyuncularının şut atma performanslarının ön test ve son testleri arasında $\alpha=0.05$ düzeyinde anlamlı bir farklılık yoktur. $\mathrm{H}_{0 \mathrm{~A} 4}$ hipotezi kabul edilmiştir.

\section{Farklııkla Öğrenme Antrenmanlarının Deney Grubu Oyuncuları Üzerindeki Etkisi}

Wilcoxon analiz testine göre turnike, dribling(top sürme), pas verme ve şut atma beceri testleri performanslarında anlamlı bir farklılık bulunmuştur $(\mathrm{p}<0.05)$.

$\mathrm{H}_{\mathrm{OB}}$ : Farklılıkla öğrenme antrenmanları uygulanan deney grubundaki 16-18 yaş aralığındaki yarışmacı genç takım oyuncularının turnike performanslarının ön test ve son testleri arasında $\alpha=0.05$ düzeyinde anlamlı bir farklılık yoktur. $\mathrm{H}_{0 \mathrm{~B} 1}$ hipotezi reddedilmiştir.

$\mathrm{H}_{1 \mathrm{~B} 1}$ : Farklılıkla öğrenme antrenmanları uygulanan deney grubundaki 16-18 yaş aralığındaki yarışmacı genç takım oyuncularının turnike performanslarının ön test ve son testleri arasında $\alpha=0.05$ düzeyinde anlamlı bir farklılık vardır. $\mathrm{H}_{1 \mathrm{~B} 1}$ hipotezi kabul edilmiştir.

$\mathrm{H}_{\text {ов2 }}$ : Farklılıkla öğrenme antrenmanları uygulanan deney grubundaki 16-18 yaş aralığındaki yarışmacı genç takım oyuncularının dribling performanslarının ön test ve son testleri arasında $\alpha=0.05$ düzeyinde anlamlı bir farklılık yoktur. $\mathrm{H}_{\mathrm{OB} 2}$ hipotezi reddedilmiştir.

$\mathrm{H}_{1 \mathrm{~B} 2}$ : Farklılıkla öğrenme antrenmanları uygulanan deney grubundaki 16-18 yaş aralığındaki yarışmacı genç takım oyuncularının dribling performanslarının ön test ve son testleri arasında $\alpha=0.05$ düzeyinde anlamlı bir farklılık vardır. $\mathrm{H}_{1 \mathrm{~B} 2}$ hipotezi kabul edilmiştir.

$\mathrm{H}_{\mathrm{OB} 3}$ : Farklılıkla öğrenme antrenmanları uygulanan deney grubundaki 16-18 yaş aralığındaki yarışmacı genç takım oyuncularının pas verme performanslarının ön test ve son testleri arasında $\alpha=0.05$ düzeyinde anlamlı bir farklılık yoktur. $\mathrm{H}_{\text {овз }}$ hipotezi reddedilmiştir.

$\mathrm{H}_{1 \mathrm{~B} 3}$ : Farklılıkla öğrenme antrenmanları uygulanan deney grubundaki 16-18 yaş aralığındaki yarışmacı genç takım oyuncularının pas verme performanslarının ön test ve son testleri arasında $\alpha=0.05$ düzeyinde anlamlı bir farklılık vardır. $\mathrm{H}_{1 \mathrm{~B} 3}$ hipotezi kabul edilmiştir.

$\mathrm{H}_{0 \mathrm{~B} 4}$ : Farklılıkla öğrenme antrenmanları uygulanan deney grubundaki 16-18 yaş aralığındaki yarışmacı genç takım oyuncularının şut atma performanslarının ön test ve son testleri arasında $\alpha=0.05$ düzeyinde anlamlı bir farklılık yoktur. $\mathrm{H}_{0 \mathrm{~B} 4}$ hipotezi reddedilmiştir. 
$\mathrm{H}_{1 \mathrm{~B} 4}$ : Farklılıkla öğrenme antrenmanları uygulanan deney grubundaki 16-18 yaş aralığındaki yarışmacı genç takım oyuncularının şut atma performanslarının ön test ve son testleri arasında $\alpha=0.05$ düzeyinde anlamlı bir farklılık vardır. $\mathrm{H}_{1 \mathrm{~B} 4}$ hipotezi kabul edilmiştir.

Çalışmada elde edilen bu bulgular sonucunda farklılıkla öğrenme antrenmanı uygulanan deney grubundaki sporcular her teknik beceri kategorisinde performans artışı göstermişlerdir. Oyuncuların performanslarındaki ön test ile son test arasında istatistiksel olarak anlamlı fark bulunmuştur $(\mathrm{p}<0.05)$. Literatürde basketbol alanında yapılmış ve çalışmamızın bulgularını destekleyen güncel çalışmalar olduğu gözlemlenmiştir. Tallir ve arkadaşları, 3’e 3 ve 5’e 5 basketbol oyunlarını karşılaştırdıkları çalışmalarında farklılıkla öğrenme sağlayan küçük saha oyunlarının gerçek oyundaki değişkenler üzerinde daha olumlu etkileri olduğu göstermiştir (Tallır ve ark., 2012).

Santos ve arkadaşları basketboldaki teknik beceriler ve motor beceriler üzerine yaptığı çalışmada, farkll1ıkla öğrenme yönteminin çeviklik antrenmanları için bir alternatif olabileceğini ve basketbol oyununda yapılan hatalarda azalmayı göstermiştir (Santos ve ark., 2017).Alpullu ve Bozkurt 2018' deki çalışmalarında basketboldaki diferansiyel öğrenme antrenmanların basketbolun temel becerileri üzerindeki performansı arttırdığı göstermişlerdir.

Schöllhorn ve ark. (2012), çalışmalarında futbol tekniği testlerinin sonuçları göz önüne alındığında, farklı öğrenme yaklaşımının üstünlüğü için net kanıtlar sunmaktadır. Bozkurt (2018) 'un genç futbolcuların diferansiyel öğrenmeden (DL) sonra teknik performansı üzerine yaptığı araştırmaya göre, sonuçlar DL' nin oyuncuların teknik performans oranlarını iyileştirdiğini gösteriyor. Diferansiyel öğrenme yaklaşımı, fonksiyonel ve aktarılabilir hareket becerilerini edinme konusunda uygun fırsatlara erken maruz bırakılması gereken genç oyuncular için özellikle uygun olabilir (Santos ve ark., 2016).

\section{Kontrol ve Deney Grubu Oyuncularının Beceri Testleri Arasındaki Farklılık}

Çalışmamızda uyguladığımız diğer bir analiz testi olan, kontrol ve deney grubunun arasındaki anlamlı farklılığı analiz ettiğimiz T testinde bütün beceri testlerinde anlamlı farklılık tespit edilmiştir. Turnike becerisi ve şut atma becerisinin ön testleri her iki grubunda sonuçlarında anlamlı fark bulunamamıştır ( $\mathrm{p}>0.05)$. Fakat son test verilerinde bu becerilerde iki grup arasında anlamlı fark tespit edilmiştir ve yapılan $\mathrm{T}$ testinde belirtilen veri ortalamalarındaki artış gözlemlenmiş̦tir ( $\mathrm{p}$ $<0.05$ ). Aynı zamanda pas verme ve dripling becerilerindeki analizlerde ön testlerde anlamlı farklılık bulunmuştur $(\mathrm{p}<0.05)$, analizler son testlerdeki verilerde ise anlamlı farklılığın olduğunu ve bu farkın deney grubunda artış gösteren verilerden dolayı oluştuğunu göstermektedir $(\mathrm{p}<0.05)$. Analizler sonucunda deney grubunun verileri kontrol grubuna oranla anlamlı bir artış ortaya koymuştur ( $\mathrm{p}>0.05)$. Bu analizlerden alınan sonuçlara göre farklılıkla öğrenme yöntemiyle çalıştırılan deney grubunun verilerinde olağan antrenmanlarına devam eden kontrol grubuna oranla da daha fazla artış olduğunu göstermektedir ve yapılan çalışmalar deney grubu üzerinde etkili olmuştur. 
$\mathrm{H}_{0 \mathrm{Cl}}$ : Ön test turnike değerlerine ilişkin kontrol ve deney grupları arasında $\alpha=0.05$ düzeyinde anlamlı bir farklılık yoktur. $\mathrm{p}>0.05$ olması sebebiyle $\mathrm{H}_{\mathrm{OC} 1}$ hipotezi kabul edilmiştir.

$\mathrm{H}_{0 \mathrm{C} 2}$ : Son test turnike değerlerine ilişkin kontrol ve deney grupları arasında $\alpha=0.05$ düzeyinde anlamlı bir farklılık yoktur. $\mathrm{p}<0.05$ olması sebebiyle $\mathrm{H}_{0 \mathrm{C} 2}$ hipotezi reddedilmiştir.

$\mathrm{H}_{0 \mathrm{C} 3}$ : Ön test dripling değerlerine ilişkin kontrol ve deney grupları arasında $\alpha=0.05$ düzeyinde anlamlı bir farklılık yoktur. $\mathrm{p}<0.05$ olması sebebiyle $\mathrm{H}_{0 \mathrm{C} 3}$ hipotezi reddedilmiştir.

$\mathrm{H}_{0 \mathrm{C} 4}$ : Son test dripling değerlerine ilişkin kontrol ve deney grupları arasında $\alpha=0.05$ düzeyinde anlamlı bir farklılık yoktur. $\mathrm{p}<0.05$ olması sebebiyle $\mathrm{H}_{0 \mathrm{C} 4}$ hipotezi reddedilmiştir.

$\mathrm{H}_{0 \mathrm{C} 5}$ : Ön test şut atma değerlerine ilişkin kontrol ve deney grupları arasında $\alpha=0.05$ düzeyinde anlamlı bir farklılık yoktur. $\mathrm{p}>0.05$ olması sebebiyle $\mathrm{H}_{0 \mathrm{C} 5}$ hipotezi kabul edilmiştir.

$\mathrm{H}_{0 \mathrm{C} 6}$ : Son test şut atma değerlerine ilişkin kontrol ve deney grupları arasında $\alpha=0.05$ düzeyinde anlamlı bir farklılık yoktur. $\mathrm{p}<0.05$ olması sebebiyle $\mathrm{H}_{0 \mathrm{C} 6}$ hipotezi reddedilmiştir.

$\mathrm{H}_{0 \mathrm{C} 7}$ : Ön test pas verme değerlerine ilişkin kontrol ve deney grupları arasında $\alpha=0.05$ düzeyinde anlamlı bir farklılık yoktur. $\mathrm{p}<0.05$ olması sebebiyle $\mathrm{H}_{0 \mathrm{C} 7}$ hipotezi redddilmiştir.

$\mathrm{H}_{0 \mathrm{C} 8}$ : Son test pas verme değerlerine ilişkin kontrol ve deney grupları arasında $\alpha=0.05$ düzeyinde anlamlı bir farklılık yoktur. $\mathrm{p}<0.05$ olması sebebiyle $\mathrm{H}_{0 \mathrm{C} 8}$ hipotezi reddedilmiştir.

Buna ek olarak alanda yapılmış olan diğer çalışmalardan aldığımız olumlu sonuçlarda basketbolda farklılıkla öğrenme antrenmanlarının gelişime katkısı olduğunu belirtmektedir.

Farklılıkla öğrenme yöntemi kullanılarak hazırlanan bazı çalışmalar, çoklu tekrarlı geleneksel çalışmalara oranla daha yararlı olduğu gözlemlenmiştir. (Schöllhorn ve ark., 2012).

Sonuç olarak, çalışmamız Alpullu ve Bozkurt' un 2018 yılındaki çalışmasından yola çıkarak hazırlanmıştır ve ek olarak çalışmamız basketbol oyunu eğitimi ileri seviyede daha büyük yaş grubunda müsabakalara katılan sporcular üzerinde haftada 4 gün farklılıkla öğrenme antrenmanları yaparak denenmiştir. Bulgular diferansiyel öğrenme grubunun daha büyük yaş grubundaki ve daha üst seviyedeki sporcuların bütün beceri performanslarında iyileşme gösterdiğini belirtmektedir. Ayrıca bu yöntem sporcuların teknik gelişim sürecini hızlandırmaktır. Çoklu tekrarlar kullanılmadığından antrenmanın toplam süresinde de ekonomi sağlandığ gözlemlenmiştir. Bununla birlikte literatürde yer alan diğer spor branşlarındaki farklılıkla öğrenme yöntemi uygulanmış çalışmalarda da başarılı sonuçlar elde edilmiş ve antrenörlerin antrenman programlarında diferansiyel öğrenme yöntemi hem küçük yaş gruplarında hem de ileri seviye sporcularda kullanılabilirliği gözlemlenmiştir.

Antrenmanların oyuncuların performansına doğrudan etki etmesi ve müsabakalarda sporcuların performansını en üst seviyeye çıkartması esastır. Bununla birlikte farklılıklaöğrenmeantrenmanlarının geleneksel antrenmanlara bir seçenek olarak antrenman programlarına eklenmesi ve bu iki yöntemin harmanlanarak sporcuları çalıştırılması öğrenim olarak etkili olacağı gözlemlenmiştir. Materyal 
kullanımının çokluğu diferansiyel antrenmanların, idman sürelerini artırsa da tekrar yöntemi kullanılmadığından sporcularda nöromuskuler yorgunluğu azaltabileceği gözlemlenmektedir. Bunlara ek olarak sporculara farklılıkla öğrenme yöntemiyle hazırlanmış hareketleri anlatmak, antrenman motivasyonunu ve ciddiyetini sağlamanın bu tarz yarışmacı takımlarda zor olduğu gözlemlenmiştir.

\section{Öneri}

Çalışmamızda tespit ettiğimiz verilerin ışığın farklılıkla öğrenme antrenmanlarının antrenmanın tüm bölümünde daha uzun sürelerle çalıştırılması sporcuların teknik becerilerinin gelişiminde daha etkili olabilir.

Çalışmalarda kullanılan geçerlilik ve güvenirliliği literatüre girmiş testlerle vardığımız sonuçlara ek olarak müsabaka döneminde farklılıkla öğrenme üzerine yapılan çalışmaların verimliliği sporcuların müsabakalardaki performansları analiz edilerek hesaplanabilir.

Ek olarak, basketbolda farklllıkla öğrenme antrenmanlarının gerçek ve üst düzey müsabakalarda mücadele eden sporcular üzerinde etkisi taktik anlayış, müsabaka içindeki hatalardan ziyade oyun içi yapılan olumlu hareketler ve alan paylaşımına etkisi gibi konuların da araştırılması gerekmektedir.

Çalışmamızdaki testlerin analizleri sonucunda bulduğumuz bulgular, basketbol antrenman programlarının hazırlanmasında antrenörlere ışık tutacağına ve literatürdeki bir boşluğu dolduracağını ummaktayız.

\section{KAYNAKLAR}

Alpullu, A., \& Bozkurt, S. (2018). The Effects Of Differential Learning Trainings On Technical Development Of Basketball School Players European Journal of Education Studies, 4(12), 72-79. doi:10.5281/zenodo.1469844

Baker, J., Côté, J., \& Abernethy, B. (2003). Learning from the experts: Practice activities of expert decision makers in sport. Research Quarterly for Exercise and Sport, 74(3), 342-347. doi:10.1080/0 2701.367.2003.10609101

Baker, J., Horton, S., Robertson-Wilson, J., \& Wall, M. (2003). Nurturing sport expertise: Factors influencing the development of elite athlete. Journal of Sports Science \& Medicine, 2(1), 1-7.

Bompa, T. O., \& Buzzichelli, C. (2018). Periodization: theory and methodology of training. Human Kinetics, 3.

Bozkurt, S. (2018).The Effects of Differential Learning and Traditional Learning Trainings on Technical Development of Football Players. Journal of Education and Training Studies, 6(4a), 25-29. doi:10.11114/jets.v6i4a.3229 
Bös, K. (1987). Heidelberger Basketball-Test: HBT. Deutscher Sportbund.

Chow, J. Y., Davids, K., Button, C., \& Renshaw, I. (2015). Nonlinear pedagogy in skill acquisition: An introduction. New York, NY: Taylor \& Francis Group.

Chow, J., Davids, K., Button, C., Shuttleworth, R., Renshaw, I., \& Araújo, D. (2007). The role of nonlinear pedagogy in physical education. Review of Educational Research, 77(3), 251-278.

Côté, J., \& Vierimaa, M. (2014). The developmental model of sport participation: 15 years after its first conceptualization. Science \& Sports, 29 (Supplement), S63-S69. doi:10.1016/j.scispo.2014.08.133

Faude, O., Koch, T., \& Meyer, T. (2012). Straight sprinting is the most frequent action in goal situations in professional football. Journal of Sports Sciences, 30(7), 625-631. doi:10.1080/02640.41 4.2012 .665940

Giblin, S., Collins, D. and Button, C. (2014). Physical Literacy: Importance, Assessment and Future Directions. Sports Medicine, 44(9), 1177-1184.

Haudum, A., Birklbauer, J., Kröll, J. and Müller, E. (2012). Constraint-led changes in internal variability in running. Journal of Sports Science and Medicine, 11, 8-15.

Higgs, C. (2010). Physical Literacy - Two approaches, one concept. SPRING Torrents, C. and Balagué, N. (2006). Dynamics system theory and sports training. Socialiniai Mokslai, 1(60), 72-83.

Jaakkola, T., Yli-Piipari, S., Huotari, P., Watt, A., \& Liukkonen, J. (2016). Fundamental movement skills and physical fitness as predictors of physical activity: A 6-year follow-up study. Scandinavian Journal Medicine Science Sports, 26(1), 74-81. doi:10.1111/sms.12407

Longmuir, P. E., Boyer, C., Lloyd, M., Yang, Y., Boiarskaia, E., Zhu, W., \& Tremblay, M. S. (2015). The Canadian assessment of physical literacy: Methods for children in grades 4 to 6 (8 to 12 years). BMC Public Health, 15(1), 767. doi:10.1186/s12889.015.2106-6

Mateus, N., Santos, S., Vaz, L., Gomes, I., \& Leite, N. (2015). The effect of a physical literacy and differential learning program in motor, technical and tactical basketball skills. Revista de Psicologi?a del Deporte, 24, 73-76.

Meier, K. V. (1988). Tirad trickery: Playing with sport and games. journal of the Philosophy and Sport, 15(1), 11-20.

Passos, P., Araújo, D., Davids, K., \& Shuttleworth, R. (2008). Manipulating constraints to train decision making in rugby union. International Journal of Sport Science \& Coaching, 3(1), 125-140.

Reinhart, B. (1981) Free throw shooting: a manual for coaches and players. Chicago, IL: Chicago Review Press. 
Santos, S., Mateus, N., Sampaio, J., \& Leite, N. (2017). Do previous sports experiences influence the effect of an enrichment programme in basketball skills? J Sports Sci, 35(17), 1759-1767. doi:10.1 080/02640.414.2016.1236206

Schöllhorn WI, Bauer HU. (1998). International Symposium on Biomechanics in Sports. In: Riehle H, Vieten M, Eds. XVI. Konstanz: Universitätsverlag; pp. 574-7.

Schöllhorn, W. I., Beckmann, H., Janssen, D., \& Drepper, J. ( 2010). Stochastic Perturbations in Athletics Field Events Enhance Skill Acquisition. Motor Learning in Practice. A constraints-led approach. London: Routledge, 69-82.

Schöllhorn, W. I., Hegen, P., \& Davids, K. (2012). The Nonlinear Nature of Learning -A Differential Learning Approach. The Open Sport Science Journal, 5, 100-112.

Shea, C. H., \&Kohl. I ,L. (1990) Specificicy and variability of practice. Research Quarterly for Exercise and Sporf, 61, 169-177

Shoenfelt, E. L., Snyder, L. A., Maue, A. E., McDowell, C. P., \& Woolard, C. D. (2002). Comparison of Constant and Variable Practice Conditions on Free-Throw Shooting. Perceptual and Motor Skills, 94, 1113-1123.

Smith, W. (2014). Fundamental movement skills and fundamental games skills are complementary pairs and should be taught in complementary ways at all stages of skill development. . Sport, Education and Society, 1-12.

Tallır, I. B. , Phılıppaerts, R., Valcke, M., Musch, E., \& Leno1r, M. (2012). Learning opportunities in 3 on 3 versus 5 on 5 basketball game play - An application of nonlinear pedagogy. International Journal of Sport and Exercise Psychology, 43, 420-437. doi:10.7352/IJSP

Torrents, C., Balagué, NPerl, J. and Schöllhorn, W. (2007). Linear and nonlinear analysis of the traditional and differential strength training. Biomedicinos Mokslai, 3(66), 39-47. 